\title{
Interferon- $\beta$ inhibits glioma angiogenesis through downregulation of vascular endothelial growth factor and upregulation of interferon inducible protein 10
}

\author{
SHINGO TAKANO, EIICHI ISHIKAWA, MASAHIDE MATSUDA, \\ TETSUYA YAMAMOTO and AKIRA MATSUMURA
}

Department of Neurosurgery, Faculty of Medicine, University of Tsukuba, Tsukuba, Ibaraki 305-8575, Japan

Received May 27, 2014; Accepted July 4, 2014

DOI: $10.3892 /$ ijo.2014.2620

\begin{abstract}
Interferon- $\beta$ (IFN- $\beta$ ) has been used clinically for malignant glioma growth inhibition. Recently IFN- $\beta$ is re-evaluated for its sensitization mechanism to the chemotherapeutic agent temozolomide, because angiogenesis is essential for malignant glioma growth. In this study, we investigated new mechanisms of inhibition of glioma angiogenesis by IFN- $\beta$. Three malignant glioma cell lines, U87, TK2 and Becker, were used for in vitro study. The effect of IFN- $\beta$ for these cell lines were evaluated by means of proliferation (MTT assay), conditioned medium induced HUVEC migration, VEGF and interferon inducible protein 10 (IP10, angiogenesis inhibitor) expression by RT-PCR and western blot analysis. SCID mouse U87 subcutaneous model and U87 implant cranial window model were used for in vivo study. The effect of IFN- $\beta$ with the models was evaluated by means of tumor growth, tumor tissue expression for VEGF and IP10, tumor tissue CD31 positive vessel densities, apoptosis and tumor microcirculation (blood velocity, interaction between leukocytes and endothelial cells). In vitro, IFN- $\beta$ upregulated IP10 expression and downregulated VEGF expression time- (4-48 h) and dose- (10-5,000 U/ml) dependently. At the same dose, glioma cell-induced HUVEC migration was inhibited, but cell proliferation was not affected. IFN- $\beta$ local and systemic injection at $10^{5} \mathrm{U}$ and at $5 \times 10^{5} \mathrm{U} /$ day, for 15 days inhibited U87 subcutaneous growth significantly. In the tumor tissues, VEGF expression and vessel densities were downregulated, but IP10 expression and apoptosis index upregulated. In addition, IFN- $\beta$ local injection increased collagen fiber deposition in the tumor tissues. IFN- $\beta 5 \times 10^{5} \mathrm{U} /$ day, s.c. injection for 7 days reversed the decreased leukocyte adhesion to
\end{abstract}

Correspondence to: Dr Shingo Takano, Department of Neurosurgery, Faculty of Medicine, University of Tsukuba, 1-1-1 Tennoudai, Tsukuba, Ibaraki 305-8575, Japan

E-mail: shingo4@md.tsukuba.ac.jp

Key words: angiogenesis, glioma, interferon- $\beta$, interferon inducible protein 10 , vascular endothelial growth factor endothelial cells, but did not affect blood velocity and vessel images. One of the important roles of IFN- $\beta$ for malignant glioma growth inhibition was anti-angiogenesis by directly inhibiting angiogenesis through downregulation of VEGF and upregulation of IP-10 and indirectly changing the tumor microcirculation and regulating the interstitial pressure.

\section{Introduction}

Interferons (IFNs) are a family of natural glycoproteins that consist of IFN- $\alpha,-\beta$ and $-\gamma$. The antiviral activity of IFNs led to their discovery, but later data revealed that they also control cell growth and differentiation, inhibit expression of oncogenes, and activate $\mathrm{T}$ lymphocytes, natural killer cells and macrophages. Therefore, the efficacy of IFN therapy for various malignancies, including malignant gliomas (1), has been investigated for many years.

Recently anti-glioma action of IFN- $\beta$ has been re-evaluated. IFN- $\beta$ markedly enhanced sensitivity to temozolomide (TMZ) via downregulation of MGMT transcription $(2,3)$. The results of the study suggest that compared to TMZ-based chemotherapy plus radiotherapy, chemotherapy with IFN- $\beta$ and TMZ and concomitant radiotherapy further improve the clinical outcomes of patients with malignant gliomas. A multicenter phase I clinical trial established that therapy with IFN- $\beta$ and TMZ is safe, well tolerated, and prolongs survival of patients with glioblastoma $(4,5)$. Taken together, IFN- $\beta$ increased the therapeutic efficiency of TMZ in cases of newly diagnosed primary glioblastoma, particularly in patients with the unmethylated MGMT promoter (6). A prospective randomized control trial to compare the clinical outcomes of newly diagnosed glioblastoma patients treated with TMZ alone or with TMZ and IFN- $\beta$ combination therapy is ongoing.

Because glioblastoma is one of the most richly neovascularized solid tumors in terms of vasoproliferation, endothelial cell hyperplasia, and endothelial cell cytology (7), antiangiogenic approach may be especially suitable for the treatment of malignant gliomas (8). Recent large clinical study clearly demonstrated the effectiveness of anti-VEGF antibody (bevacizumab) for malignant glioma $(9,10)$. Antiangiogenic activity of IFN- $\beta$ has been reported previously, IFN- $\beta$ inhibits some growth factors (bFGF, interleukin 8$)(11,12)$ and gelatinase $(13)$ 
transcription and/or protein production. In this study, we investigated the antiangiogenic effect of IFN- $\beta$ for malignant gliomas in vitro and in vivo, especially about VEGF production, angiogenic stimuli and inhibitor balance, and tumor microcirculation that are not previously proven mechanisms as antiangiogenic actions of IFN- $\beta$.

\section{Materials and methods}

Human glioma cell lines and culture conditions. The human glioma cell line U-87 MG was obtained from the American Type Culture Collection (Rockville, MD). The human glioma cell line TK2 was established from glioblastoma at the Department of Neurosurgery, University of Tsukuba. The human glioma cell line, Becker, was a generous gift. Cells were maintained in MEM supplemented with $10 \%$ FCS in a humidified atmosphere containing $5 \% \mathrm{CO}_{2}$ at $37^{\circ} \mathrm{C}$.

Human umbilical cord vein endothelial cells (HUVECs) harvested from umbilical cords were a generous gift of Dr Okuda (University of Tsukuba). HUVECs were maintained with collagen coated flasks (Iwaki Glass, Tokyo, Japan) in E300 medium (Kyokuto, Tokyo, Japan) which are designed for HUVEC culture containing $2 \%$ fetal calf serum, heparin, aFGF and EGF.

Reagents. Human IFN- $\beta$ was a gift from Toray Industries, Inc. (Tokyo, Japan).

Cell proliferation assay (MTT assay). Cell proliferation assays were performed using the CellTiter 96 ${ }^{\mathrm{TM}}$ Aqueous Non-Radioactive Proliferation Assay (Promega Corp., Madison, WI) as described previously (14). This assay measures the reduction of a tetrazolium compound (3-(4,5-dimethylthiazol-2-yl)-5-(3-carboxymethoxyphenyl)-2-(4-sulfophenyl)$2 \mathrm{H}$-tetrazolium), by living cells to a formazan product. Briefly, the glioma cells, $1 \times 10^{5} / \mathrm{ml}$ in DMEM with $10 \%$ FCS, were plated in 96-well plates (Becton Dickinston, Lincoln Park, NJ) at 5,000 cells. After 24-h incubation, the various doses of IFN- $\beta$ (10 to $5,000 \mathrm{U} / \mathrm{ml})$ were added to the wells. The cells were incubated for 48, 96, $144 \mathrm{~h}$. At the end of incubation period, to the microplate wells were added $20 \mu \mathrm{l}$ of a freshly prepared combined tetrazolium compound and an electron coupling reagent (phenazine methosulfate) solution, then incubated for $2 \mathrm{~h}$ at $37^{\circ} \mathrm{C}$, and the optical density at $490 \mathrm{~nm}$ was read on an automatic microplate reader (Model 550, Bio-Rad). The experiment was repeated at least three times in triplicate wells for each concentration of IFN- $\beta$.

Western blot analysis. The tissues and the cell pellets were homogenized with a ultrasonic homogenizer on ice in $1 \mathrm{ml}$ of extraction buffer [25 mM Tris, $100 \mathrm{mM} \mathrm{NaCl}, 20 \mathrm{mM}$ $\mathrm{NH}_{4} \mathrm{HCO}_{3}$, pH 7.5, protease inhibitor cocktail; Complete Mini (Roche) one tablet] per $100 \mathrm{mg}$ wet weight of tissue and the protein lysates were obtained after centrifugation at $50,000 \mathrm{x} \mathrm{g}$ for $30 \mathrm{~min}$ at $4^{\circ} \mathrm{C}$. Lysates containing $50 \mu \mathrm{g}$ of total protein, as estimated by the method of Bradford using bovine serum albumin as a standard, were separated on $12 \%$ SDS-polyacrylamide gel, electroblotted onto $0.2 \mu \mathrm{m}$ nitrocellulose membrane (Bio-Rad) and were immunoassayed with rabbit polyclonal anti-VEGF antibody (A-20, $100 \mu \mathrm{g} / \mathrm{ml}$,
Santa Cruz Biotechnology, Santa Cruz, CA) at the dilution of 1:200 and mouse monoclonal anti-human IP-10 antibody (500 $\mu \mathrm{g} / \mathrm{ml}$, Dako, Glostrup, Denmark) at the dilution of 1:100. The immunocomplexes formed were visualized with alkaline phosphatase-conjugated anti-rabbit or anti-mouse immunoglobulin $\mathrm{G}(\mathrm{IgG})$ using ECL western blot analysis system (Amersham Pharmacia Biotech).

U87 SCID mouse subcutaneous model. After the implantation of $1 \times 10^{5}$ U87 cells in the flank of 6 weeks old male SCID mouse (Clea Japan), U87 tumor tissue fragments were removed and then re-implanted into another SCID mouse. Harvested tumor fragments, $1 \mathrm{~mm}^{3}$ in size, were implanted into the flank of 17 SCDI mice. The animals were divided into 3 groups randomly; 5 control group, 5 IFN- $\beta$ low dose group, 7 IFN- $\beta$ high dose group. IFN- $\beta$ treatment was started at day 7 after the implantation when the subcutaneous tumor reached $5 \mathrm{~mm}$ in size. IFN- $\beta$ was locally injected adjacent to the tumor $1 \times 10^{5} \mathrm{U}$ (low dose group) and $5 \times 10^{5} \mathrm{U}$ (high dose group) once daily for 15 days. Size of the subcutaneous tumor was measured by caliper. At 15 days after the treatment, the tumor tissue was removed. A part of the tissue was immediately fixed in $10 \%$ phosphate-buffered formalin for $48 \mathrm{~h}$, paraffin-embedded, and used for routine pathological diagnosis and immunohistochemistry. The other part of the tissue was immediately frozen with liquid nitrogen and stored at $-70^{\circ} \mathrm{C}$. Two mice of the 7 IFN- $\beta$ high dose group survived for next 20 days without any treatment and tumor volume was measured.

Similar set of the U87 subcutaneous tumor experiments were repeated with IFN- $\beta$ systemic (intraperitoneal) injection instead of local injection. Fifteen mice were divided into 3 groups; 5 control, 5 IFN- $\beta$ low dose and 5 IFN- $\beta$ high dose. This systemic injection experiment was only used to measure the tumor volume between three groups.

RNA isolation and reverse transcription polymerase chain reaction $(R T-P C R)$. Total RNA was extracted from IFN- $\beta$ treated and control frozen tumor tissues ( 4 controls, 4 IFN- $\beta$ low dose, 4 IFN- $\beta$ high dose) and glioma cell lines treated with IFN- $\beta$ using RNeasy mini kit (Qiagen GmbH, Germany). Quantitative RT-PCR for IP10 and VEGF mRNA in glioma cells and glioma tissues has been described previously (15). We performed RT-PCR with the GeneAmp ${ }^{\mathrm{TM}}$ RNA PCR Kit (Perkin-Elmer Cetus, Norwalk, CT). Briefly, $1 \mu \mathrm{g}$ of total RNA was reverse transcribed by $\mathrm{MuLV}$ reverse transcriptase in the presence of random hexamer, followed by indicated cycles of PCR reaction $\left(95^{\circ} \mathrm{C}\right.$ for $1 \mathrm{~min}, 55^{\circ} \mathrm{C}$ for $1 \mathrm{~min}$ and $72^{\circ} \mathrm{C}$ for $1 \mathrm{~min}$ ) in the presence of $2 \mu \mathrm{M}$ IP10 specific primers (32 cycles), VEGF specific primers (28 cycles), or the $\beta$-actin specific primers (16 cycles) as a control. The IP10 primers were designed, the reverse primer (5'-GATTCAGACATCTCTTCTCACCC-3') is complementary to positions $295-275$, and the forward primer (5'-TGACTCTAAGTGGCATTCAAGG-3') corresponds to positions 107-128 (16). The VEGF primers included the reverse primer (5'-CCTGGTGAGAGATCTGGTTC-3') spanning bases 861-842 and the forward primer (5'-TCGGGCCTCCGA AACCATGA-3') spanning bases $141-160$. The $\beta$-actin primers included the reverse primer (5'-GGAGTTGAAGGTAGTTTC GTG-3') spanning bases 2429-2409 and the forward primer 
(5'-CGGGAAATCGTGCGTGACAT-3') spanning bases 2107-2126. The predicted sizes of the amplified IP10 and $\beta$-actin DNA products were 188 and $214 \mathrm{bp}$, respectively. The VEGF primers were chosen because they amplified exons 3 to 8 and allowed for distinguishing between the different VEGF splicing variants. PCR products of 516 and $648 \mathrm{bp}$ corresponded with VEGF121 and VEGF165, respectively. The quantification of these RT-PCR product levels was performed on a Macintosh computer using the public domain NIH Image program (developed at the US National Institute of Health).

Antibodies and immunohistochemistry. The Dako LSAB Kit for mouse and rabbit primary antibody (Dako) was used. Tissue sections were deparaffined and incubated with $10 \%$ normal goat serum in PBS for $20 \mathrm{~min}$. The sections were then incubated with a polyclonal anti-VEGF antibody, A-20 (Santa Cruz Biotechnology) at a dilution of $1 / 100(1 \mu \mathrm{g} / \mathrm{ml} \mathrm{IgG})$ in PBS overnight at $4^{\circ} \mathrm{C}$, and a monoclonal anti-mouse $\mathrm{CD} 31$ antibody (BD Pharmingen) at a dilution of $1 / 200$ in PBS for $60 \mathrm{~min}$ at room temperature. Chromatographically purified mouse $\mathrm{IgG}$ and rabbit $\operatorname{IgG}$ (Dako) at the same $\operatorname{IgG}$ concentration were used as negative controls. Sections were incubated with biotinconjugated goat anti-mouse or anti-rabbit immunogloblin for $10 \mathrm{~min}$, followed by washing in PBS for $10 \mathrm{~min}$. The sections were then incubated with peroxidase conjugated streptavidin solution for $5 \mathrm{~min}$, followed by washing in PBS for $5 \mathrm{~min}$. Sections were then stained with freshly prepared aminoethylcarbazole solution for $10 \mathrm{~min}$, followed by washing for 5 min in tap water. The sections were then counterstained with hematoxylin and mounted with aqueous mounting media. The intracellular VEGF immunostaining was assessed separately for tumor and endothelial cells using a semiquantitative scale (-, not detected; +, moderate; ++, strong).

Tumor vascular density. Vascular density was scored using the vasoproliferative component of the MAGS (microscopic angiogenesis grading system) that has been used to quantify angiogenesis in a variety of tumors (17). The number of vessels at $200 \mathrm{X}$ field $\left(1.0 \mathrm{~mm}^{2}\right)$ was measured in microvessel 'hot spots' (i.e., microscopic areas containing the most dense collections of microvessels, as initially identified under low power magnification) with the use of an Olympus microscope, AHBT3 (Olympus, Tokyo, Japan) on CD31 stained tissue sections. Vascular density was defined by averaging the number of vessels in the three most vascularised areas.

Histochemical detection of apoptotic cells and determination of apoptotic index. Apoptotic cells were visualized using the ApopTag in situ detection kit (Oncor, Gaithersburg, MD) as described previously (15). The staining procedures were modified based on the manufacturer's instructions. Briefly, after deparaffinization and rehydration, the tissues were digested with proteinase $\mathrm{K}(20 \mu \mathrm{g} / \mathrm{ml}$ in PBS; Wako, Osaka, Japan) for $20 \mathrm{~min}$ at room temperature and washed. Slides were then put into $3 \% \mathrm{H}_{2} \mathrm{O}_{2}$ for $5 \mathrm{~min}$ and washed with PBS. After adding the equilibration buffer for $10 \mathrm{~min}$. TdT enzyme was pipetted onto the sections, which were then incubated at $37^{\circ} \mathrm{C}$ for $1 \mathrm{~h}$. The reaction was stopped by putting sections in stop/wash buffer. After washing, anti-digoxigenin-peroxidase was added to the slides. Slides were washed, stained with diaminobenzi- dine (DAKO) substrate, and counterstained with hematoxylin. A specimen known to be positive for apoptotic cells was used as positive control for subsequent staining. Substitution of TdT with distilled water was used as a negative control. The apoptotic index was expressed as the ratio of positively staining tumor cells to all tumor cells, given as a percentage for each case. At least five representative areas without necrosis in a section were selected by light microscopy using 40 - to 200 -fold magnification. A minimum of 3,000 cells was counted under a 400 -fold magnification. Positively staining tumor cells with the morphological characteristics of apoptosis were identified using standard criteria, including chromatin condensation, nucleolar disintegration, and formation of crescentic caps of condensed chromatin at the nuclear periphery.

Glioma conditioned medium induction of HUVEC migration. Glioma cells $\left(1 \times 10^{5}\right)$ were plated into a 6-well plate. After incubation for $24 \mathrm{~h}$ in MEM with $10 \%$ FCS, the medium was changed to MCDB107 with $0.5 \%$ FCS containing various concentrations of IFN- $\beta$. After $48 \mathrm{~h}$ incubation, the conditioned medium was harvested and the concentration of VEGF in glioma conditioned medium was measured using Quantikine $^{\mathrm{TM}}$ Human VEGF Immunoassay (R\&D Systems, Minneapolis, MN). Endothelial cell migration was evaluated by 24 -well modified Boyden chamber (Coster, Cambridge, MA) as described previously. The chamber contains Nucleopore polycarbonate membranes $(8-\mu \mathrm{m}$ pore size) that had been soaked overnight in $0.1 \%$ gelatin in $0.1 \%$ acetic acid. A total of $100 \mu \mathrm{l}$ of HUVECs, $2 \times 10^{6}$ cells $/ \mathrm{ml}$ in MCDB107 with $0.5 \% \mathrm{FBS}$, was plated in upper well and $600 \mu \mathrm{l}$ of collected conditioned medium was added to lower wells. The assembly was incubated for $6 \mathrm{~h}$. The membrane was removed, fixed in methanol, stained with hematoxylin and the cells in upper surface were gently wiped with cotton swab. The insert was mounted on glass slide. The number of migrated cells was counted from at random five fields using x 25 magnification. Data were expressed as cells per field. One field corresponded to $0.09 \mathrm{~mm}^{2}$ (width, $309 \mu \mathrm{m}$ x height, $291 \mu \mathrm{m}$ ) of the membrane area. The experiment was repeated two times in quadruplicate for each concentration.

SCID mouse U87 implant cranial window model and quantitation of intravital tumor microcirculation. U87 tumor tissue fragment $\left(1 \mathrm{~mm}^{3}\right)$ was implanted on the surface of the SCID mouse cranial window $(n=3)$. IFN- $\beta$ was injected intraperitoneally for 7 days, and then the cranial window was evaluated for tumor microcirculation. Three series of experimental studies to visualize blood flow dynamics of the tumor microcirculation and to quantify their microhemodynamic parameters were performed (18).

First, by labeling plasma component, the tumor microvasculature was visualized and mapped to obtain information on vascular architecture and dimensions of microvessels. To enhance the contrast of microvessel images against a dark background, a solution of FITC-labeled dextran (FITC-Dx, MW 150,000; Sigma, St. Louis, MO) was intravenously injected $(20 \mathrm{mg} / \mathrm{ml}, 2 \mathrm{ml} / \mathrm{kg})$. This permitted bright fluorescence images of the vascular lumen, and enabled mapping of the vascular architecture and accurate measurements of luminal diameter. The diameter of microvessels was measured 

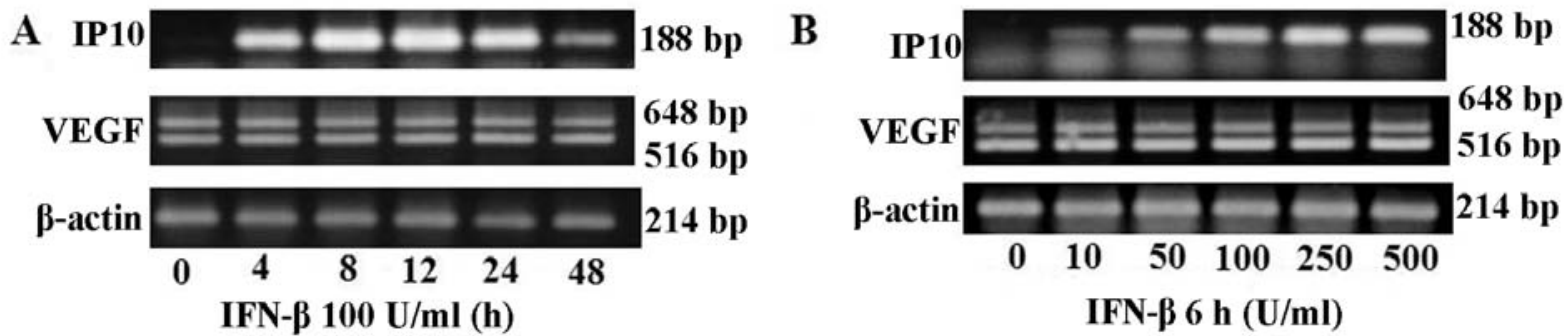

Figure 1. RT-PCR analysis for the transcripts of IP10, VEGF and $\beta$-actin in glioma cells, (A) TK2 and (B) Becker. (A) No IP10 mRNA expression in the control, but IFN- $\beta 100 \mathrm{U} / \mathrm{ml}$ induced IP10 expression time-dependently between 4- and 48-h treatment. (B) No IP10 mRNA expression in the control, but IFN- $\beta$ treatment for $6 \mathrm{~h}$ induced IP10 expression dose-dependently between 10 and $500 \mathrm{U} / \mathrm{ml}$ of IFN- $\beta$.

carefully with a vernier caliper on the standstill frame of the video-recorded images by playback of a high quality video-cassette recorder (Model BR-S605B). Their average values were calculated from five measurements in each vessel.

Secondary, to visualize the flow behavior of erythrocytes in vivo and to measure their velocities, a part of erythrocytes was labeled fluorescently and injected intravenously. The arterial blood $(0.2 \mathrm{ml})$ of a donor mouse was collected from a tail vein into a $1.5 \mathrm{ml}$ test tube containing heparin (100 units) for anticoagulation. The erythrocytes were separated from the plasma by centrifugation and were washed twice with pysiological saline solution. These erythrocytes were then incubated at room temperature with a phosphate-buffered saline (PBS) solution, adjusted to $\mathrm{pH} 7.8$, containing $1 \mathrm{mg} / \mathrm{ml}$ fluorescein isothiocyanate (FITC). After $60 \mathrm{~min}$ of incubation, the labeled cells were washed twice with a saline solution containing $1 \%$ bovine serum albumin to remove uncombined fluorescent dyes. The final volume percent of the labeled cells was adjusted to $50 \%$ by adding an isotonic saline solution. These suspensions were injected intravenously through a tail vein. The erythrocyte velocity was calculated by a frame-by-frame analysis and averaged for at least 10 measurements.

Thirdly, to analyze the leukocyte behavior and the leukocyte-endothelium interaction, leukocytes were also labeled fluorscently. A working solution of rhodamine 6G (Sigma) was prepared by dissolving $10 \mathrm{mg}$ of the dye in $40 \mathrm{ml}$ of physiological saline. This solution was diluted with saline until a final concentration of $50 \mu \mathrm{g} / \mathrm{ml}$. The optimal concetration of the dye for imaging leukocytes was determined from several preliminary experiments. Each solution was freshly prepared on the day of the experiment and filtered through a $0.22 \mu \mathrm{m}$ filter before each experiment. Leukocytes were found to be visualized by injecting a small bolus of $2 \mathrm{ml} / \mathrm{kg}$ of the solution intravenously. Arolling leukocyte was defined as one that marginates along the vessel wall and is clearly dissociated from the bulk of the blood flow. An adhering leukocyte was defined as one that stays stationary during at least $15 \mathrm{sec}$ of the 30-sec observation period (19).

Statistical analyses. Vascular density, MIB-1 positivity, apoptosis index, tumor volumes, densitometric value of VEGF, IP10 and $\beta$-actin, and the parameter of tumor microcirculation (diameter, velocity, number of leukocyte) were expressed as mean \pm SD. Statistically significant differences between the groups were determined using a one-way analysis of variance and the Tukey's test. All p-values are two-sided; values are considered statistically significant for $\mathrm{p}<0.05$.

\section{Results}

Antiangiogenic activity of IFN- $\beta$ in vitro. RT-PCR analysis demonstrated IFN- $\beta$ upregulated IP10 mRNA expression time- (4-48 h) and dose- (10-500 U/ml) dependently, but not VEGF mRNA expression (Fig. 1). However, VEGF protein concentration and secretion in the conditioned medium was decreased time- and dose-dependently by IFN- $\beta$ treatment (Fig. 2). IP10 protein in cell extracts was increased time- and dose-dependently with IFN- $\beta$ treatment (Fig. 3). Increased VEGF and decreased IP10 protein expression of glioma cells treated with IFN- $\beta$ at $100 \mathrm{U} / \mathrm{ml}$ for $48 \mathrm{~h}$ resulted in the inhibition of HUVECs migration (Fig. 4A). By contrast, glioma cell proliferation was not affected by IFN- $\beta$ treatment for $48 \mathrm{~h}$ at the dose ranging from 10 to 5,000 U/ml (Fig. 4B).

IFN- $\beta$ inhibition of glioma growth in subcutaneous tumor. IFN- $\beta$ local injection as well as systemic injection for 15 days significantly inhibited U87 subcutaneous growth (Fig. 5). VEGF protein expression of U87 tumor tissues was decreased dramatically in the IFN- $\beta$ high dose treatment, while IP10 protein expression increased (Fig. 6A). RT-PCR analysis demonstrated that IP10 mRNA expression of the tumor tissues was not detected in any of control group. Upregulation of IP10 mRNA expression of the tumor tissues was observed in 2 of 4 IFN- $\beta$ low dose group and all 4 in IFN- $\beta$ high dose group. VEGF mRNA expression of the tumor tissues was not affected by RT-PCR analysis (Fig. 6B). Immunohistochemistry clearly demonstrated high VEGF expression in the control tumor tissues and decreased VEGF expression in the IFN treated tumor tissues (Fig. 7). VEGF expression was strong in 5 of 5 control group and in none of IFN- $\beta$ high and low dose group. CD31 positive vessel densities were significantly decreased both in the IFN- $\beta$ low and high treated groups compared to control group (Table I). In IFN- $\beta$ high treated group, MIB-1 positivities were significantly low and apoptosis indices were significantly high compared to the control animals (Table I). The growth inhibitory effect of IFN- $\beta$ was reversible because the tumor did re-start to grow after the discontinuation of the IFN- $\beta$ treatment at similar degree to control tumors (Fig. 5A). In addition, IFN- $\beta$ treatment increased collagen fiber deposition in the tumor tissues, 
Table I. U87 tumor pathology 25 days after interferon- $\beta$ treatment.

\begin{tabular}{lcccc}
\hline & $\begin{array}{c}\text { Tumor volume } \\
\left(\mathrm{mm}^{3}\right)\end{array}$ & $\begin{array}{c}\text { MIB-1 } \\
(\%)\end{array}$ & $\begin{array}{c}\text { Apoptosis } \\
\text { index }(\%)\end{array}$ & $\begin{array}{c}\text { Vessel density } \\
\left(\mathrm{no} . / \mathrm{mm}^{2}\right)\end{array}$ \\
\hline Control & $12,371.4 \pm 3,195.3$ & $38.2 \pm 3.9$ & $0.20 \pm 0.001$ & $89.0 \pm 11.4$ \\
IFN- $\beta$ low & $1,523.8 \pm 1,354.4^{\mathrm{b}}$ & $31.4 \pm 6.4$ & $0.56 \pm 0.104$ & $54.0 \pm 11.1^{\mathrm{b}}$ \\
IFN- $\beta$ high & $769.0 \pm 339.0^{\mathrm{b}}$ & $21.8 \pm 2.7^{\mathrm{a}}$ & $1.00 \pm 0.024^{\mathrm{b}}$ & $78.3 \pm 8.8^{\mathrm{b}}$ \\
\hline
\end{tabular}

${ }^{\mathrm{a}} \mathrm{p}<0.05,{ }^{\mathrm{b}} \mathrm{p}<0.01$ compared to control.

\section{A MW (kDa)}

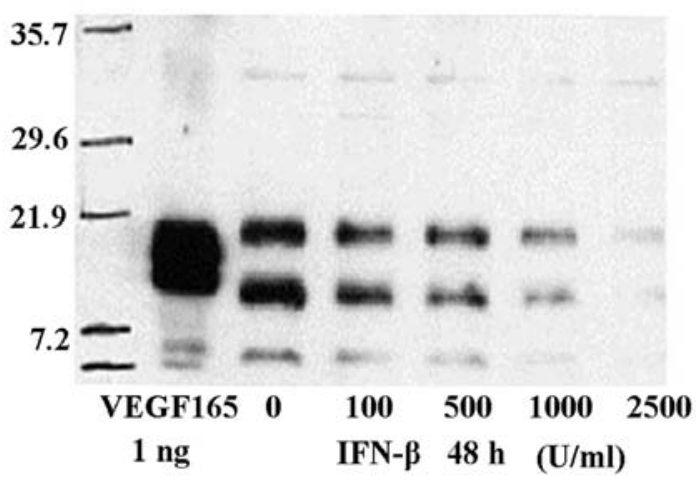

B

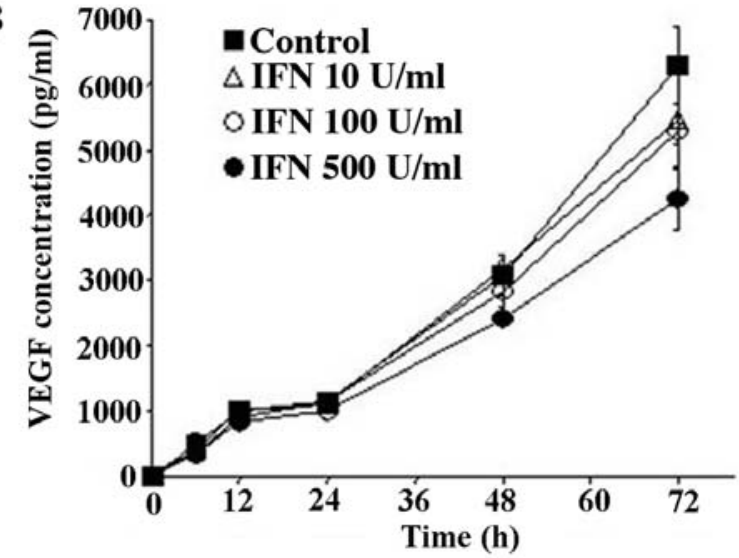

Figure 2. VEGF protein expression of glioma cells. (A) Western blot analysis showed dose-dependent inhibition of Becker secretion of VEGF by IFN- $\beta$ treatment. (B) VEGF concentration of conditioned medium measured by ELISA was decreased time and dose dependently by IFN- $\beta$. The same samples were used for western blot analysis after 50X concentration.
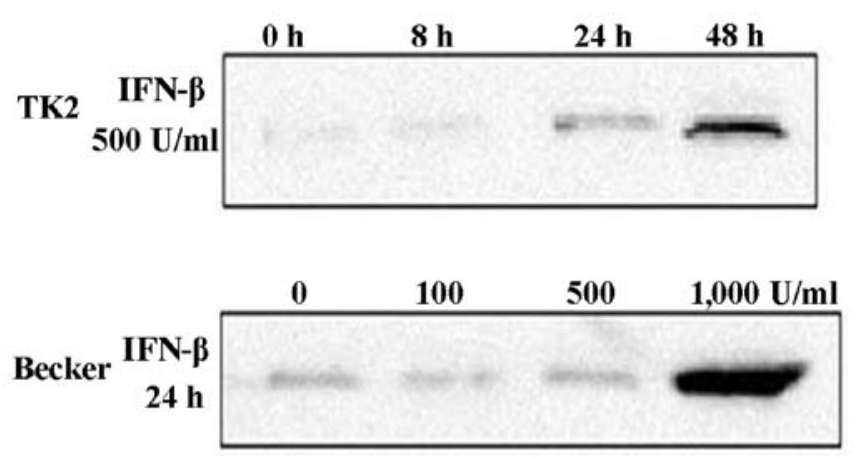

Figure 3. IP10 protein expression of glioma cells. Western blot analysis showed time- (TK2) and dose- (Becker) dependent increase of IP10 expression.

which was demonstrated by Masson's Trichrome stain (Fig. 7C and D). The increase was not observed in the group of systemic IFN- $\beta$ treatment.

IFN- $\beta$ inhibition of glioma microcirculation. With the cranial window model, 7 days after the U87 fragment implantation, tortuous vessels grew around the fragment where red blood cell velocity and the degree of leukocyte adhesion and rolling significantly decreased compared to those of the normal cortical vein at the diameter of $20-80 \mu \mathrm{m}$. IFN- $\beta$ systemic treatment for 7 days dramatically reversed the decreased leukocyte adhesion and rolling in the U87 glioma graft, while tortuous vessel morphology and red blood cell velocity were not unchanged (Table II).

\section{Discussion}

Our study clearly demonstrated that IFN- $\beta$ inhibited glioma angiogenesis in three different aspects, in vitro, subcutaneous tumor, and intracerebral tumor microcirculation. The local and systemic administration of IFN- $\beta$ to SCID mouse bearing human glioblastoma cells decreased expression of VEGF, induced expression of IP10, reduced vascular density and inhibited reversible tumor growth. Also the systemic administration of IFN- $\beta$ significantly inhibited glioma growth and reversed the microcirculation of the glioma tissues to that of the non-tumor brain tissue, suggesting the anti-proliferative effect is not due to only high local concentrations of the protein. Among these manifestations, simultaneous action with upregulation of VFGF and downregulation of IP10 is unique. Because angiogenesis is influenced by the balance between stimulatory and inhibitory molecules released by the tumor and its microenvironment, any decrease in a stimulatory molecule or an increase in an inhibitory molecule should reduce the level of neovascularization within the tumor.

Antiangiogenic action of IFN- $\beta$. Clinical data concluded that the systemic chronic administration of IFN- $\alpha$ or IFN- $\beta$ accelerate the regression of richly vascularized tumors, e.g., life-threatening hemangiomas of infancy (20), hemangio- 

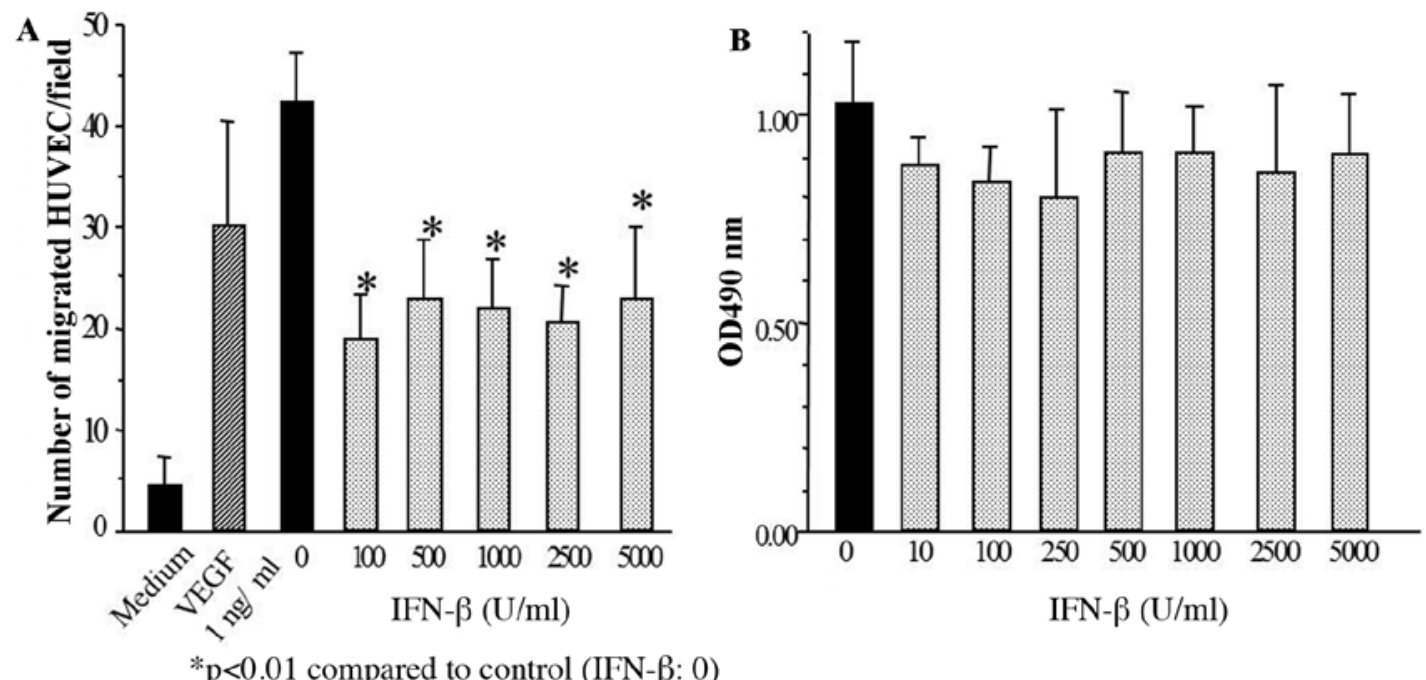

Figure 4. Endothelial cell migration and tumor proliferation. (A) HUVEC migration induced by glioma cell (Becker) conditioned medium. IFN- $\beta$ at $100 \mathrm{U} / \mathrm{ml}$ significantly inhibited HUVEC migration. (B) IFN- $\beta$ at the dose range 10-5,000 U/ml for $48 \mathrm{~h}$ did not inhibit glioma cell (Becker) proliferation measured by MTT assay.

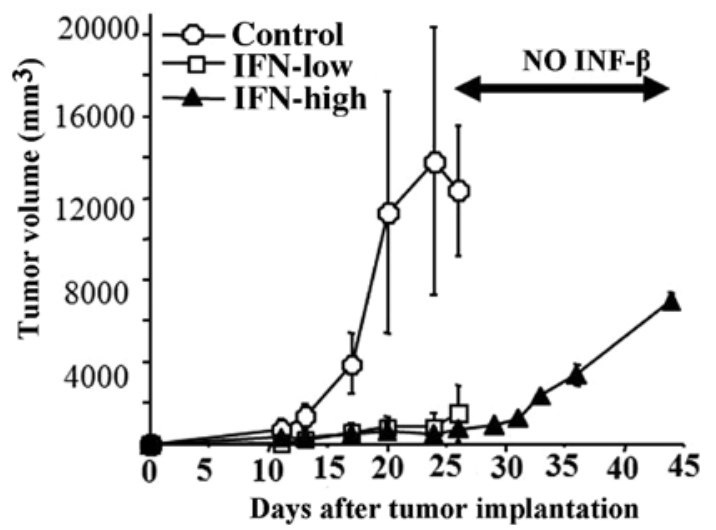

Figure 5. IFN- $\beta$ inhibition of U87 glioma growth in subcutaneous tumors. Intra tumoral injection of IFN- $\beta$ low and high dose inhibited U87 subcutaneous tumor growth. Inhibition of tumor growth re-started after discontinuation of IFN- $\beta$ (after 26th day of tumor implantation).

endotheliomas (21), hemangiopericytoma (22) and Kaposi's sarcomas (23). The mechanisms responsible for this remarkable clinical outcome remained unclear. IFN- $\beta$ can inhibit angiogenesis by several mechanisms.

In vitro, IFN- $\beta$ inhibits endothelial cell proliferation (11), endothelial cell migration (24), downregulation of transcription and production of bFGF protein (11), interleukin 8 (25) and collagenase type IV (13), all of which are involved in the angiogenic response. In addition, our data demonstrate IFN- $\beta$ inhibits production of VEGF protein, although the effects is marginal, and induces production of IP10, endogenous angiogenesis inhibitor, resulting in inhibition of HUVEC migration induced by glioma conditioned medium.

However, the antiangiogenic mechanism of IFN- $\beta$ for malignant gliomas has not been investigated comprehensively. Boethius et al (26) reported that systemic administration of IFN- $\alpha$ to patients with glioblastoma multiforme induced marked changes in the tumor vasculature, which supports the notion that IFN- $\alpha$ may have an effect on tumor vessels. We demonstrated that IFN- $\beta$ inhibits glioma cell induced endothelial cell migration, VEGF secretion in the glioma cell conditioned medium, and VEGF expression and vessel densities in the glioma tissues. IFN- $\beta$ is superior to IFN- $\alpha$ in terms of anti-angiogenic effects (27). The above strongly suggests that the in vivo antitumor effect of IFN- $\beta$ in malignant gliomas may be mediated, at least in part, via the angiogenesis inhibition rather than the antiproliferative activity on tumor cells. Hong et al (28) demonstrated the level of VEGF and bFGF expression of U87 cells was not influenced by IFN- $\beta$ treatment at concentrations from $10-500 \mathrm{IU} / \mathrm{ml}$ for 24 and $72 \mathrm{~h}$. They measured the expression of cell extract and we measured secreted protein of VEGF.

IFN- $\beta$ inhibits VEGF secretion. We reported that IFN- $\beta$ treatment inhibited glioma cell VEGF secretion in vitro and glioma angiogenesis with downregulation of VEGF in glioma tissue. The investigations concerning to relationship of VEGF inhibition and IFN- $\beta$ are very limited. VEGF promotes phosphorylation-dependent ubiquitination and degradation of IFN receptor and ensuing attenuation of IFN- $\alpha / \beta$ signaling; these processes appear to be required for efficient angiogenesis (29). In another report, the antitumor effect of IFN- $\beta$ was offset by the tumor-progressive character of endothelial progenitor cells (EPCs) and the tumor growth, and the vascular density of tumor tissues increased by the co-implanted EPCs were decreased upon IFN- $\beta$ treatment. In addition, overall expression levels of VEGF in tumor tissues that were decreased upon IFN- $\beta$ treatment (30).

Recent clinical studies indicate that anti-VEGF agents are important for the treatment of angiogenesis-dependent diseases. The approaches used today are mainly based on the development and administration of functional recombinant protein antagonists that either neutralize the extracellular VEGF function or block VEGF signaling in target cells. The disadvantages of current therapeutic strategies are many, 


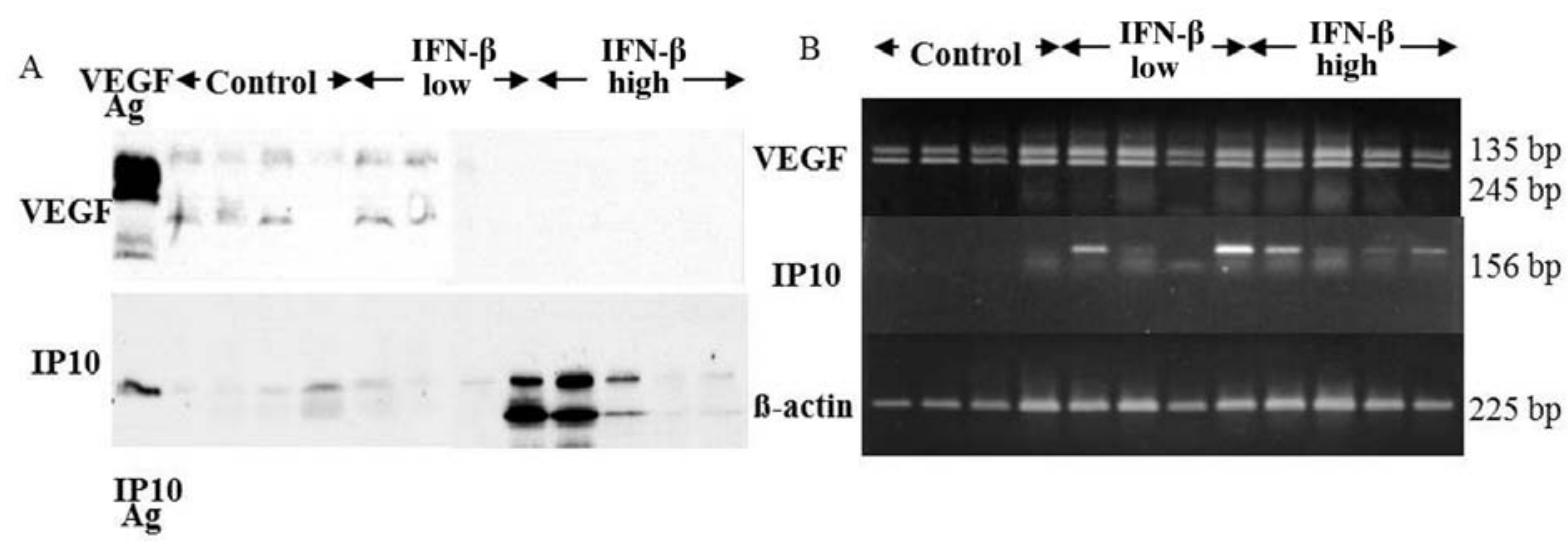

Figure 6. VEGF and IP10 expression in the IFN- $\beta$ treated and control tumor tissues. (A) Western blot analysis shows IFN- $\beta$ high dose treatment inhibited VEGF protein expression and induced IP10 protein expression in the tumor tissues. (B) RT-PCR analysis shows IFN- $\beta$ induction of IP10 mRNA expression in 2 of 4 low dose group and in all of the high dose group.

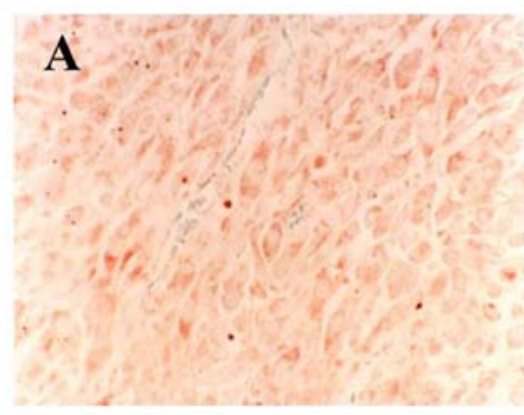

B

Figure 7. (A and B) VEGF immunohistochemistry and (C and D) Masson's Trichrome stain of (A and C) control and (B and D) IFN- $\beta$ high dose group. Note marked decreased expression of VEGF and increased collagen fiber deposition in the treated group. Original magnification, x100.

Table II. U87 tumor microcirculation with interferon-beta treatment.

\begin{tabular}{lcccc}
\hline & $\begin{array}{c}\text { Vessel } \\
\text { diameter } \\
(\mu \mathrm{m})\end{array}$ & $\begin{array}{c}\text { Red blood cell } \\
\text { velocity } \\
(\mu \mathrm{m} / \mathrm{sec})\end{array}$ & $\begin{array}{c}\text { Vessel } \\
\text { diameter } \\
(\mu \mathrm{m})\end{array}$ & $\begin{array}{c}\text { Leukocyte } \\
\text { adhesion, rolling } \\
(\mathrm{no} . / 600 \mathrm{sec})\end{array}$ \\
\hline No tumor & $23.9 \pm 10.5$ & $475.6 \pm 175.3$ & $45.6 \pm 34.7$ & $112.1 \pm 80.5$ \\
U87 tumor & $19.8 \pm 8.9$ & $248.0 \pm 91.2$ & $35.0 \pm 21.0$ & $27.9 \pm 14.7$ \\
U87 tumor, IFN & $20.0 \pm 0.2$ & $277.2 \pm 8.7$ & $66.0 \pm 15.2$ & $306.8 \pm 131.5^{\mathrm{a}}$ \\
\hline
\end{tabular}

${ }^{\mathrm{a}} \mathrm{p}<0.05$ compared to no treatment.

including difficulties in manufacturing active recombinant protein, high-dose requirements, high costs for manufactures and consumers, and the probable need for lifetime treatment of
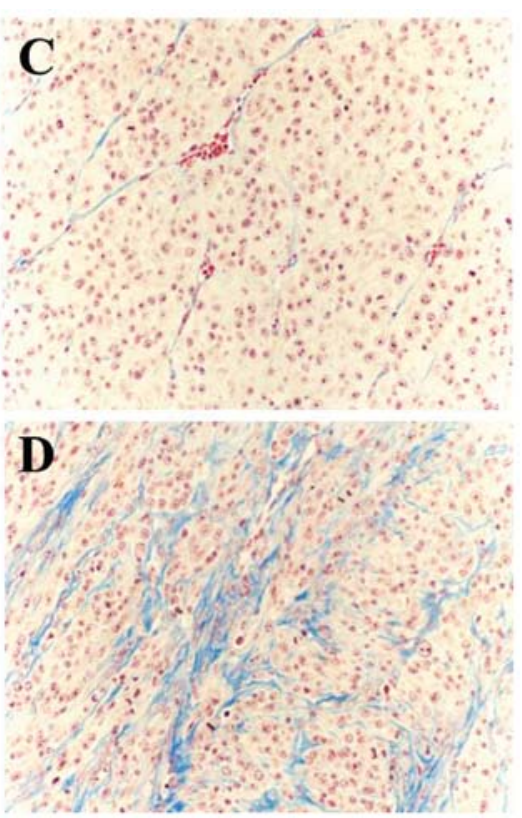
on neuroendocrine tumor cell lines (32), by a PI3 kinase inhibitor in melanoma (33) and by IFN- $\alpha$ in melanoma cell line (34). PI3 kinase activation may occur via loss of phosphatase and tensin homolog (PTEN) that is closely related to IFN- $\beta$ sensitivity in glioma (35). Taken together, IFN- $\beta$ treatment appears to be one of novel strategies of anti-angiogenesis on glioma by preventing VEGF secretion.

IP10 antiangiogenic action. IFN- $\beta$ upregulates IP10 from a number of cells, including keratinocytes, fibroblasts, endothelial cells, mononuclear phagocytes and cancer cells. IFN- $\beta$ may shift the biological balance of ELR+ (IL-8) and ELR-CXC (IP10) chemokines, leading to reduced net angiogenic activity (36). IP10 is a potent inhibitor of not only ELR+ CXC chemokine (IL-8) but also the unrelated angiogenic factors bFGF and VEGF (36).

The production of IP10 from adenocarcinoma and squamous carcinoma tumors was inversely correlated with their growth. SCID mouse bearing tumors were given intratumor injection of recombinant human IP10. IP10 treatment resulted in a $>40 \%$ reduction in tumor size and mass, respectively. The mechanism of growth inhibition by intratumor administration of IP10 was found to be correlated with a reduction in primary tumor-derived angiogenic activity and neovasculature (37). IP10 protein expression was inversely correlated with vascular density and clinical behavior in endometrial cancer (38). We demonstrated IFN- $\beta$ treatment shifted the balance of VEGF/IP-10 into angiostatic state in glioma cells and tissue. Interestingly, IP-10 has been identified as a major biological marker mediating cancer severity and may be utilized as a prognostic indicator for various cancers (39). IP-10 shows potential as a biological response marker of IFN- $\beta$ in glioma.

IFN- $\beta$ affects tumor microcirculation in gliomas. Yuan et al (40) and Foltz et al (19) reported the intravital microscopic analysis of malignant gliomas transplanted into a cranial window preparation. Although cranial window model to visualize tumor microcirculation is not a new method, this method is superior to the present MRI based evaluation of tumor vasculature, such as perfusion MRI (41) and vessel architecture imaging (42). Intravital analysis with the cranial window model can provide us information of the tumor microcirculation, such as leukocyte adhesion to vessel wall in addition to vessel architecture. Malignant glioma caused decreased number of leukocyte adhesion to endothelial cells, which is a key factor in the tumor microcirculation. We demonstrated that IFN- $\beta$ influenced the glioma microcirculation with reversal of the inhibition of leukocyte adhesion. IFN- $\beta$ inhibits activated leukocyte migration through human brain microvascular endothelial cell monolayer (43). Implantation of IFN- $\beta$ producing cells upregulated the adhesion molecules, ICAM-1 and VCAM-1 (27). TNF- $\alpha$ by co-treatment with IFN- $\beta$ increased soluble VCAM-1 in human cerebral endothelial cells (44). VEGF antagonist, such as soluble Flt1 (soluble form of VEGF receptor) increases ICAM1, VCAM1 and leukocyte adhesion in endothelial cells (45). Our data suggest IFN- $\beta$ increased ICAM1 and VCAM1 directly or indirectly through inhibition of VEGF production with glioma cells, resulting reversal of leukocyte adhesion.
Taken together, the reversal effect of IFN- $\beta$ on the tumor microcirculation that is considered as a concept for vascular normalization (46), could be one of the mechanisms by which IFN- $\beta$ treatment exerts antiangiogenic effects in malignant glioma.

IFN- $\beta$ affects matrix reaction. Matrix modifications were characterized on histological sections stained with Masson's Trichrome stain. Collagen deposition or structure of IFN- $\beta$ treated animals appeared to be thicker than in the non-treated ones. The collagen deposition was prominently observed with local injection of IFN- $\beta$, but not with systemic treatment. Combined with the similar increase of collagen fiber in the stromal tissue surrounding the IFN-producing tumor cells (27), high concentration of IFN- $\beta$ in the tissues is needed for this thicker collagen deposition. Thicker collagen deposition may increase the interstitial pressure in the tumor and decrease diffusion of angiogenic molecules, e.g., VEGF, to the endothelial cells, resulting in inhibition of angiogenesis (47). However IFNs are species specific. Our studies on the effect of the IFNs concerning the host microenvironment (immune, endothelial cells and extracellular matrix) have some limitations.

In conclusion, one of the important roles of IFN- $\beta$ for malignant glioma growth inhibition was anti-angiogenesis by directly inhibiting angiogenesis through downregulation of VEGF and upregulation of IP-10 and indirectly changing the tumor microcirculation and regulating the interstitial pressure. At present, the clinical effectiveness of IFN- $\beta$ for human malignant gliomas is limited. Several published studies have shown that anti-angiogenic agents act synergistically with chemotherapy or radiation therapy. Also the growth inhibitory effect was reversible and non-toxic even with high dose of IFN- $\beta$ in our study, suggesting combination therapy with IFN- $\beta$ and chemotherapy or radiation therapy for long-term usage will overcome many of the limitations of individual treatment.

\section{Acknowledgements}

We gratefully acknowledge Norio Ohshima, Department of Biomedical Engineering, University of Tsukuba, Koji Tsuboi, Proton Medical Research Center, University of Tsukuba, and Youji Mitsui, Biophysiology, Tokushima Bunri University for the excellent discussion, Toray Industries, Inc. and Daiichi Pharmaceutical Co. for supply of human interferon- $\beta$, and Yoshiko Tsukada, Makiko Miyagawa, and Momoyo Ito for the excellent technical assistance. This study was supported in part by a Grant-in-Aid for Scientific Research from the Ministry of Education, Culture, Sports, Science and Technology of Japan (S.T.), Japan Brain Foundation (S.T.) and Japanese Foundation for Multidisciplinary Treatment of Cancer (S.T.).

\section{References}

1. Fine HA, Wen PY, Robertson M, O'Neill A, Kowal J, Loeffler JS and Black PML: A phase I trial of a new recombinant human $\beta$-interferon (BG9015) for the treatment of patients with recurrent gliomas. Clin Cancer Res 3: 381-387, 1997.

2. Natsume A, Ishii D, Wakabayashi T, Tsuno T, Hatano H, Mizuno $M$ and Yoshida J: IFN-beta down-regulates the expression of DNA repair gene MGMT and sensitizes resistant glioma cells to temozolomide. Cancer Res 65: 7573-7579, 2005. 
3. Yoshino A, Ogino A, Yachi K, Ohta T, Fukushima T, Watanabe T, Katayama Y, Okamoto Y, Naruse N and Sano E: Effect of IFN-beta on human glioma cell lines with temozolomide resistance. Int J Oncol 35: 139-148, 2009.

4. Wakabayashi T, Kayama T, Nishikawa R, Takahashi $H$, Hashimoto N, Takahashi J, Aoki T, Sugiyama K, Ogura M, Natsume A and Yoshida J: A multicenter phase I trial of combination therapy with interferon-beta and temozolomide for high-grade gliomas (INTEGRA study): the final report. J Neurooncol 104: 573-577, 2011.

5. Colman H, Berkey BA, Maor MH, Groves MD, Schultz CJ, Vermeulen S, Nelson DF, Mehta MP, Yung WK; Radiation Therapy Oncology Group: Phase II Radiation Therapy Oncology Group trial of conventional radiation therapy followed by treatment with recombinant interferon-beta for supratentorial glioblastoma: results of RTOG 9710. Int J Radiat Oncol Biol Phys 66: 818-824, 2006.

6. Motomura K, Natsume A, Kishida Y, Higashi H, Kondo Y, Nakasu Y, Abe T, Namb H, Wakai K and Wakabayashi T: Benefits of interferon-beta and temozolomide combination therapy for newly diagnosed primary glioblastoma with the unmethylated MGMT promoter: a multicenter study. Cancer 117: 1721-1730, 2011.

7. Brem S, Cotran R and Folkman J: Tumor angiogenesis: a quantitative method for histologic grading. J Natl Cancer Inst 48: 347-356, 1972.

8. Norden AD, Drappatz J and Wen PY: Novel anti-angiogenic therapies for malignant gliomas. Lancet Neurol 7: 1152-1160, 2008.

9. Nagane M, Nishikawa R, Narita Y, Kobayashi H, Takano S, Shinoura N, Aoki T, Sugiyama K, Kuratsu J, Muragaki Y, Sawamura Y and Matsutani M: Phase II study of single-agent bevacizumab in Japanese patients with recurrent malignant glioma. Jpn J Clin Oncol 42: 887-895, 2012.

10. Chinot OL, Wick W, Mason W, Henriksson R, Saran F, Nishikawa R, Carpentier AF, Hoang-Xuan K, Kavan P, Cernea D, Brandes AA, Hilton M, Abrey L and Cloughesy T: Bevacizumab plus radiotherapy-temozolomide for newly diagnosed glioblastoma. N Engl J Med 370: 709-722, 2014.

11. Singh RK, Gutman M, Bucana CD, Sanchez R, Llansa N and Fidler IJ: Interferons $\alpha$ and $\beta$ down-regulate the expression of basic fibroblast growth factor in human carcinomas. Proc Natl Acad Sci USA 92: 4562-4566, 1995.

12. Dinney CPN, Bieleberg DR, Perrotte P, Reich R, Eve BY, Bucana CD and Fidler IJ: Inhibition of basic fibroblast growth factor expression, angiogenesis, and growth of human bladder carcinoma in mice by systemic interferon- $\alpha$ administration. Cancer Res 58: 808-814, 1998.

13. Gohji K, Fidler IJ, Tsan R, Radinsky R, von Eschenbach AC, Tsuruo $T$ and Nakajima M: Human recombinant interferon-beta and -gamma decrease gelatinase production and invasion by human KG-2 renal-carcinoma cells. Int J Cancer 58: 380-384, 1994.

14. Takano S, Gately S, Neville ME, Herblin WF, Gross JL, Engelhard H, Perricone M, Eidsvoog K and Brem S: Suramin, an anticancer and angiosuppressive agent, inhibits endothelial cell binding of basic fibroblast growth factor, migration, proliferation, and induction of urokinase-type plasminogen activator. Cancer Res 54: 2654-2660, 1994.

15. Takano S, Tsuboi K, Matsumura A, Tomono Y, Mistui Y and Nose T: Expression of the angiogenic factor thymidine phosphorylase in human astrocytic tumors. J Cancer Res Clin Oncol 126: $145-152,2000$

16. Boorsma DM, de Haan P, Willemze R and Stoof TJ: Human growth factor (huGRO), interleukin-8 (IL-8) and interferon-gamma-inducible protein (gamma-IP-10) gene expression in cultured normal human keratinocytes. Arch Dermatol Res 286: 471-475, 1994.

17. Takano S, Yoshii Y, Kondo S, Maruno T, Shirai S and Nose T: Concentration of vascular endothelial growth factor in the serum and tumor tissue of brain tumor patients. Cancer Res 56 : 2185-2190, 1996

18. Suzuki T, Yanagi K, Ookawa K, Hatakeyama K and Ohshima N: Flow visualization of microcirculation in solid tumor tissues: intravital microscopic observation of blood circulation by use of a confocal laser microscope. Front Med Biol Eng 7: 253-263, 1996.

19. Foltz RM, McLendon RE, Friedman HS, Dodge RK, Bigner DD and Dewhirst MW: A pial window model for the intracranial study of human glioma microvascular function. Neurosurgery 36: 976-984, 1995 .
20. Ezekowitz RAB, Mulliken JB and Folkman J: Interferon alfa $2 \mathrm{a}$ therapy for life-threatening hemangiomas in infancy. N Engl J Med 324: 1456-1463, 1992.

21. Orchard PJ, Smith CM, Woods WG, Day DL, Dehner LP and Shapiro R: Treatment of haemangio endotheliomas with alpha interferon. Lancet 2: 565-567, 1989.

22. Kirn DH and Kramer A: Long-term function from disease progression with interferon alfa therapy in two patients with malignant hemangiopericytoma. J Natl Cancer Inst 88: 764-765, 1996.

23. Real FX, Qettgen HF and Kroun SE: Kaposi's sarcoma and the acquired immunodeficiency syndrome: treatment with high and low doses of recombinant leukocyte $\alpha$ interferon. J Clin Oncol 4: 544-551, 1986.

24. Stout AJ, Gresser I and Thompson WD: Inhibition of wound healing in mice by local interferon- $\beta$ injection. Int $\mathbf{J}$ Exp Pathol 74: 79-85, 1993.

25. Oliveira IC, Sciavolino PJ, Lee TH and Vilcek J: Downregulation of interleukin 8 gene expression in human fibroblasts: unique mechanism of transcriptional inhibition by interferon. Proc Natl Acad Sci USA 89: 9049-9053, 1992.

26. Boethius J, Blomgren H, Collins VP, Greitz T and Strander H: The effect of human interferon- $\alpha$ administration to patients with glioblastoma multiforme. Acta Neurochir 68: 239-251, 1983.

27. Rozera C, Carlei D, Lollini PL, De Giovanni C, Musiani P, Di Carlo E, Belardelli $F$ and Ferrantini M: Interferon (IFN)- $\beta$ gene transfer into TS/A adenocarcinoma cells and comparison with IFN- $\alpha$. Am J Pathol 154: 1211-1222, 1999.

28. Hong YK, Chung DS, Joe YA, Yang YJ, Kim KM, Park YS, Yung WKA and Kang JK: Efficient inhibition of in vivo human malignant glioma growth and angiogenesis by interferon- $\beta$ treatment at early stage of tumor development. Clin Cancer Res 6: 3354-3360, 2000.

29. Zheng H, Qian J, Carbone CJ, Leu NA, Baker DP and Fuchs SY: Vascular endothelial growth factor-induced elimination of the type 1 interferon receptor is required for efficient angiogenesis. Blood 118: 4003-4006, 2011.

30. Xiao HB, Zhou WY, Chen XF, Mei J, Lv ZW, Ding FB, Li GQ, Zhong $\mathrm{H}$ and Bao CR: Interferon- $\beta$ efficiently inhibited endothelial progenitor cell-induced tumor angiogenesis. Gene Ther 19: 1030-1034, 2012

31. Björndahl M, Cao R, Eriksson A and Cao Y: Blockage of VEGF-induced angiogenesis by preventing VEGF secretion. Circ Res 94: 1443-1450, 2004.

32. Von Marschall A, Scholz A, Cramer T, Schafer G, Schirner M, Oberg K, Wiedenmann B, Hocker M and Rosewicz S: Effects of interferon alpha on vascular endothelial growth factor gene transcription and tumor angiogenesis. J Natl Cancer Inst 95: 421-437, 2003.

33. Bedogni B, O'Neill MS, Welford SM, Bouley DM, Giaccia AJ, Denko NC and Powell MB: Topical treatment with inhibitors of the phosphatidylinositol 3'-kinase/Akt and $\mathrm{Raf} /$ mitogen-activated protein kinase kinase/extracellular signal-regulated kinase pathways reduces melanoma development in severe combined immunodeficient mice. Cancer Res 64: 2552-2560, 2004.

34. Raig ET, Jones NB, Varker KA, Benniger K, Go MR, Biber JL, Lesinski GB and Carson WE III: VEGF secretion is inhibited by interferon-alpha in several melanoma cell lines. J Interferon Cytokine Res 28: 553-561, 2008 .

35. Yoshino A, Tashiro S, Ogino A, Yachi K, Ohta T, Fukushima T, Watanabe T, Katayama Y, Okamoto Y, Sano E and Tsumoto $\mathrm{K}$ Gene expression profiles predicting the response to IFN- $\beta$ and a combination of temozolomide and IFN- $\beta$ in malignant gliomas. Int J Oncol 39: 529-542, 2011.

36. Keane MP, Arenberg DA, Moore BB, Addison CL and Strieter RM: CXC chemokines and angiogenesis/angiostasis. Proc Assoc Am Physicians 110: 288-296, 1998.

37. Arenberg DA, Kunkel SL, Polverini PJ, Morris SB, Burdick MD, Glass MC, Taub DT, Iamettoni MD, Whyte RI and Strieter RM: Interferon- $\gamma$-inducible protein 10 (IP-10) is an angiostatic factor that inhibits human non-small cell lung cancer (NSCLC) tumorigenesis and spontaneous metastases. J Exp Med 184: 981-982, 1996.

38. Sato E, Fujimoto J and Tamaya T: Expression of interferongamma-inducible protein 10 related to angiogenesis in uterine endometrial cancers. Oncology 73: 246-251, 2007

39. Liu M, Guo S and Stiles JK: The emerging role of CXCL10 in cancer (Review). Oncol Lett 2: 583-589, 2011. 
40. Yuan F, Salehi HA, Boucher Y, Vasthrae US, Tuma RF and Jain RK: Vascular permeability and microcirculation of gliomas and mammary carcinomas transplanted in rat and mouse cranial windows. Cancer Res 54: 4564-4568, 1994.

41. Fatterpekar GM, Galheigo D, Narayana A, Johnson G and Knopp E: Treatment-related change versus tumor recurrence in high-grade gliomas: a diagnostic conundrum - use of dynamic susceptibility contrast-enhanced (DSC) perfusion MRI. AJR Am J Roentgenol 198: 19-26, 2012.

42. Emblem KE, Mouridsen K, Bjornerud A, Farrar CT, Jennings D, Borra RJ, Wen PY, Ivy P, Batchelor TT, Rosen BR, Jain RK and Sorensen AG: Vessel architectural imaging identifies cancer patient responders to anti-angiogenic therapy. Nat Med 19: 1178-1183, 2013.

43. Lou J, Gasche Y, Zheng L, Giroud C, Morel P, Clements J, Ythier $A$ and Grau GE: Interferon- $\beta$ inhibits activated leukocyte migration through human brain microvascular endothelial cell monolayer. Lab Invest 79: 1015-1025, 1999.
44. Kallmann B, Hummel V, Lindenlaub T, Ruprecht K, Toyka KV and Rieckmann P: Cytokine-induced modulation of cellular adhesion to human cerebral endothelial cells is mediated by soluble vascular cell adhesion molecule-1. Brain 123: 687-697, 2000.

45. Cindrova-Davies T, Sanders DA, Burton GJ and Charnock-Jones DS: Soluble FLT1 sensitizes endothelial cells to inflammatory cytokines by antagonizing VEGF receptor-mediated signalling. Cardiovasc Res 89: 671-679, 2011.

46. Goel S, Wong AH and Jain RK: Vascular normalization as a therapeutic strategy for malignant and nonmalignant disease. Cold Spring Harb Perspect Med 2: a006486, 2012.

47. Boucher E, Unemori B, Seed B and Jain RK: Relaxin increases the transport of large molecules in high collagen content tumors. Proc Am Assoc Cancer Res 41: abs 64, 2000. 